\title{
Chapter 5 \\ Socioeconomic Inequalities in Civic \\ Learning in Nordic Schools: Identifying \\ the Potential of In-School Civic \\ Participation for Disadvantaged Students
}

\author{
Bryony Hoskins, Lihong Huang, and Cecilia Arensmeier
}

\begin{abstract}
This chapter provides an analysis of the complex role of Nordic schools in both enhancing and reducing socioeconomic inequalities in civic competences. A multilevel analysis method was used to examine the IEA International Civic and Citizenship Education Study (ICCS) 2009 and 2016 data of all four Nordic countries. The results show that unequal access to civic learning (in-school civic participation and open classroom climate) exist in all Nordic countries. We found differences in access within schools in which students with more advantages experienced greater opportunities to participate. Additionally, we found differences between schools. Those schools that had an intake with a higher proportion of socioeconomically advantaged students tended to provide more civic learning opportunities and open classroom climates. Inequalities in access to civic learning activities manifested itself in different ways in schools across the Nordic countries. There is some evidence that this happens more regularly in Sweden than Finland, though Norway recorded the highest levels of unequal access inside schools, and no Nordic country provides equal access to all the forms of civic learning we studied. At the same time, however, there were forms of civic learning in Nordic schools that were found to reduce socioeconomic inequalities in civic competences. The results showed that when disadvantaged students gained access to civic learning, they mostly appeared to benefit either the same or more from the experience than their more advantaged peers. A unique contribution of this chapter to the field of citizenship education is that we found that in-school civic participation can compensate for a disadvantaged background for developing future electoral participation and civic knowledge in students from disadvantaged backgrounds.
\end{abstract}

\author{
B. Hoskins $(\bowtie)$ \\ Department of Social Sciences, University of Roehampton, London, UK \\ e-mail: bryony.hoskins@ roehampton.ac.uk \\ L. Huang \\ Norwegian Social Research—NOVA, Oslo Metropolitan University, Oslo, Norway \\ e-mail: lhuang@oslomet.no \\ C. Arensmeier \\ Department of Humanities, Education and Social Sciences, Örebro University, Örebro, Sweden \\ e-mail: cecilia.arensmeier@oru.se
}

(C) The Author(s) 2021

H. Biseth et al. (eds.), Northern Lights on Civic and Citizenship Education,

IEA Research for Education 11,

https://doi.org/10.1007/978-3-030-66788-7_5 
Keywords Socioeconomic inequality $\cdot$ Civic knowledge $\cdot$ Political self-efficacy $\cdot$ Voting $\cdot$ Participation in school $\cdot$ Open classroom climate $\cdot$ Nordic countries $\cdot$ Citizenship education - International Civic and Citizenship Education Study (ICCS)

\subsection{Introduction}

The Nordic countries have long and well-respected traditions of maintaining low levels of socioeconomic inequality (Piketty 2013). The Nordic welfare model is well known for using the education system as policy tool for fostering equality (Lundahl 2016), and countries' education systems achieve high levels of equality in many outcomes (Bauer and Riphahn 2006; OECD 2019). The countries are known for healthy democracies and highly engaged citizens (Hoskins and Mascherini 2009), who are fairly satisfied with how their democracies function (Fora et al. 2020). In contrast, since the Second World War, much of the Western world has become increasingly unequal (Piketty 2013) and more dissatisfied with democracy (Fora et al. 2020), and it has suffered from mounting social inequalities in political engagement (Hoskins and Janmaat 2019). This feeling of political alienation not only excludes certain voices from decision-making processes but also creates untapped frustration, which populist and extremist parties have exploited in referendums and elections (Huber and Ruth 2017; Kriesi 2014). These parties and their political agendas have successfully positioned themselves as outsiders agitating against the political elite and have had some success in politically mobilizing disaffected and lower socioeconomic groups, as exemplified by the United Kingdom's 2016 referendum on European Union membership, United States President Donald Trump's 2016 election, and the victories of populist anti-immigrant parties in the 2018 Hungarian and Italian parliamentary elections. Socioeconomic inequalities within the education system and unequal access to civic learning have been identified as important contributors to socioeconomic inequalities in political engagement (Hoskins and Janmaat 2019).

This chapter investigates if Nordic education systems are following these trends. There are signs of increasing income inequality in Nordic countries (Aaberge et al. 2018), and radical right-wing populist parties have established themselves in all four countries (Widtfeldt 2018). Are there now signs of socioeconomic inequalities in civic learning in Nordic schools as well? This chapter focuses on identifying the role Nordic schools are playing in reducing and increasing socioeconomic inequalities in the levels of students' civic competences. ${ }^{1}$ In this regard, we address two issues: access to civic learning and differential gains from experiencing the opportunities offered in schools.

\footnotetext{
${ }^{1}$ Civic competence is defined in this chapter as the "knowledge, skills, values, and attitudes that enable a person to become an active citizen" (Hoskins et al. 2011, p. 84).
} 


\subsection{Education Equality and the Nordic Education System}

Nordic countries are associated with an education model that prioritizes education equality and social justice (Lundahl 2016). Nordic education systems have aimed at enabling equal access to high-quality education regardless of students' social backgrounds by developing a comprehensive education model in which ability grouping between or even within schools is largely prohibited (Lundahl 2016; Telhaug et al. 2006). The Nordic comprehensive education system, which was originally developed in the 1960s, has been tested and strained by the influence of global neoliberal education debates (Lundahl 2016). Nevertheless, there are differences across the Nordic countries to the extent that policy changes have been introduced and educational inequalities have risen. Of the four countries, Finland has been identified as maintaining a fully comprehensive education system, and it has low levels of education inequality (measured by the amount of variation in PISA [Programme for International Student Assessment] outcomes) and comparatively high levels of average education performance (Parker et al. 2018). In PISA studies, Finland, Denmark, and Norway are all well below the average OECD level of explained variances in cognitive scores by socioeconomic status (SES), while Sweden meets the international average (OECD 2019; Skolverket 2019). Sweden has also been identified as a country in which education inequalities have been on the rise since the 1990s, with the introduction of free schools, increasingly run by corporations for profit, and a market for competition for students between schools (Lundahl 2016). Up until 2012, the average educational performance in Sweden, as measured by PISA scores, was also declining, and this paralleled the increased levels of variations between schools and students (Parker et al. 2018). The last two PISA studies showed some improvement in Swedish scores, though higher levels of education inequality remained when compared to the other Nordic countries (Skolverket 2019). Building from this context, we might expect to find differences between the Nordic countries in the International Association for the Evaluation of Educational Achievement (IEA) International Civic and Citizenship Education Study (ICCS) data as well, with greater education inequalities in Sweden, although we note that Sweden does not have high levels of inequality in its PISA results when compared to other OECD countries.

\subsection{The Role of School in Reproducing Inequalities in Political Engagement}

Hoskins and Janmaat's (2019) theory of the social reproduction of inequalities in political engagement identifies two ways in which schools can reinforce and reproduce socioeconomic inequalities in political engagement. First, schools may fail to provide the same level of access to civic learning opportunities, either differentiating opportunities inside a school according to socioeconomic background of the students 
or differentiating teaching methods between schools according to the different socioeconomic intake. Second, schools may fail by providing learning opportunities from which advantaged students benefit more than disadvantaged ones, which has an accelerating effect. This can happen when students who have developed higher levels of competence in their home lives are able to excel more than others in a school-run activity.

In the United Kingdom context, a lack of access to learning political engagement in school was found to contribute to the reproduction of existing socioeconomic inequalities in political engagement (Hoskins and Janmaat 2019). No accelerating effects were found. Nevertheless, a systematic analysis of the Nordic countries on these issues has yet to be undertaken. Research on Denmark found inequalities in access to open classroom climates in the ICCS 2016 data (Deimel et al. 2020). Research on Sweden found unequal access to civic learning activities in the 2009 ICCS data (Hoskins and Janmaat 2019), and research on Sweden using IEA Civic Education Study (CIVED) 1999 data suggested that students in schools with a higher advantaged-student intake reported higher levels of open classroom climates (Almgren 2006).

The second aspect was the accelerating effects of privileged students benefiting more from learning opportunities than their disadvantaged counterparts because they have experience and skills on which to build. The only research that we have been able to identify that found an accelerated effect was based in Belgium, where Hooghe and Dassonneville (2013) found that students who had a higher level of political knowledge benefitted more from civic education classes in terms of enhanced political engagement.

An alternative theory suggests that young people from disadvantaged backgrounds can benefit more from a school learning experience, and this has been called the compensatory effect (Campbell 2008). The premise behind this concept is that socioeconomic inequality in political engagement is transmitted from one generation to the next through political socialization at home. When working-class children benefit more from a certain learning opportunity, it compensates for missing parental socialization and disrupts or mitigates the transmission process (Campbell 2008). In other words, access for less advantaged students to open classroom climates and in-school political activities may reduce inequalities, as these students can catch up in terms of their political learning.

Several scholars have identified education's compensatory effects on aspects of civic competence (Campbell 2008; Castillo et al. 2015; Deimel et al. 2020; Gainous and Martens 2012; Hoskins et al. 2017; Hoskins and Janmaat 2019). These scholars have mostly identified compensatory benefits in terms of students acquiring a greater amount of civic education (Deimel et al. 2020; Gainous and Martens 2012; Hoskins et al. 2017; Hoskins and Janmaat 2019). Campbell's (2008) research in the United States suggested that open classroom climates had a compensatory effect on future civic engagement. Nevertheless, Castillo et al. (2015), using the Chilean ICCS sample, and Persson (2015), using the Swedish sample from the CIVED 1999 study, found no differential effects of classroom climates on intentions to politically engage. Persson (2015) suggested that the difference between his results and those of Campbell could be ascribed to Sweden's greater level of equality: if social inequality is less 
pronounced in the first place, it is not surprising to find no compensatory effects for disadvantaged groups. However, as levels of inequality have risen in Sweden since 1999, one wonders if those results have changed. Our research examines whether different forms of learning can compensate for young people having a disadvantaged background in the four Nordic countries today.

\subsection{How Can Schools Facilitate the Learning of Civic Competence?}

In this chapter, we will explore two forms of learning civic competence-open classroom climate and in-school civic participation activities. We selected these methods because one of the prominent principles in understanding the teaching and learning of civic competence is learning through participation (Hoskins and Janmaat 2019). This processes of learning is understood to occur through open dialogue and the practicing of political engagement, and it has been widely identified through empirical research to be an effective way to learn the skills of political engagement (Hoskins et al. 2012; Hoskins et al. 2017; Hoskins and Janmaat 2019; Keating and Janmaat 2016; Knowles et al. 2018). The evidence suggests that young people learn to become politically engaged in real-world environments or contexts that reflect the real world, such as mock elections. Learning is a social process developed through interaction with others and within the communities in which students live (Hoskins et al. 2012). Using this approach, schools can be understood as communities that young people join and in which they participate in negotiations of norms, meanings, and rules.

\subsubsection{Open Classroom Climate}

The most frequently cited participatory method of civic learning is an open climate for classroom discussion (Campbell 2008; Hahn 1998; Hoskins et al. 2012; Keating and Janmaat 2016; Knowles et al. 2018; Quintelier and Hooghe 2012; Torney-Purta 2002). This refers to a situation in which students feel free to ask questions, bring up issues for discussion, express their own opinions, make up their own minds, perceive that teachers respect their opinion, and be taught by teachers who present different sides to an argument. The characteristics of a classroom based on these principles align with participatory approaches to learning in which it occurs via interaction, negotiation, and joint enterprise. There is a great deal of research that has drawn on both cross-sectional and longitudinal data to demonstrate that the open classroom learning method is effective in enhancing political engagement (Campbell 2008; Hoskins et al. 2012; Keating and Janmaat 2016; Knowles et al. 2018; Quintelier and Hooghe 2012; Torney-Purta 2002), positive attitudes towards political engagement (Geboers et al. 2013), critical thinking (ten Dam and Volman 2004), citizenship skills (Finkel and Ernst 2005), and political knowledge (McDevitt and Kiousis 2006). 


\subsubsection{In-School Civic Participation Activities}

Participatory processes of learning political engagement also occur when young people are offered the chance to practice civic engagement and decision-making at school (Hoskins et al. 2012; Keating and Janmaat 2016; Knowles et al. 2018). This can be accomplished through activities involving class councils, school parliaments, clubs, societies, and mock elections, and there is considerable evidence of their effectiveness (Hoskins et al. 2012; Hoskins and Janmaat 2019; Keating and Janmaat 2016). Youth participation activities are said to lead to the development of different aspects of civic competences, such as deliberation, compromise, public speaking, the expressing of opinions, the learning of how to work in groups, and the assimilating of other people's opinions (Quintelier 2008). Additionally, they are also said to provide students with greater awareness of the issues in their communities and build the efficacy needed to become involved in the creation of community change (Keating and Janmaat 2016; McFarland and Thomas 2006). Finally, longitudinal data have demonstrated that in-school civic activities have direct and sustainable effects on voting (Keating and Janmaat 2016) and indirect effects on enhancing levels of civic competence while students are in school (Beck and Jennings 1982).

\subsubsection{Civic Competence}

In this chapter, the term "civic competence" is defined as the "knowledge, skills, values, and attitudes that enable a person to become an active citizen" (Hoskins et al. 2011, p. 84). European countries have established a wide variety of attributes needed to become civically competent (Barrett 2020; Hoskins et al. 2011, 2014). In this chapter we will focus on three aspects of them. First, we will focus on civic knowledge as measured by the IEA ICCS testing of student understanding and ability in order to apply knowledge in four domains: civic society and systems, civic principles, civic participation, and civic identities (Schulz et al. 2017). Second, citizenship selfefficacy, which has been found to be strongly associated with actual levels of political engagement (e.g., Blais 2000; Moeller et al. 2014). Third, intended future electoral participation, which has also been found to be strongly associated with actual voter turnout (Achen and Blais 2010). These two attitudinal measures were constructed from student responses to a survey in the ICCS study (for more details, see the Sect. 5.5).

Accordingly, this chapter investigates two research questions: (1) are there inequalities in students' access to participatory forms of learning in schools in Nordic countries? (2) Do these activities offer differential learning of civic competences according to students' SES? 


\subsection{Data and Measures}

The data used in this chapter are from Nordic countries that participated in the 2009 and 2016 IEA ICCS studies of grade 8 students (grade 9 in Norway). ${ }^{2}$ Table 5.1 provides the descriptive statistics of the scales developed from the ICCS student survey data in 2009 and 2016, which were used in this chapter's analysis. We included two self-reported measures related to learning political engagement: open classroom climate and students' in-school civic participation, both of which had been developed by IEA. The open-classroom-climate scale was derived from student responses to a six-item question asking when and how often teachers encouraged their students to form their own opinions, express them, respect those of others, and raise current issues when discussing politics or society during regular lessons. The scale of students' in-school civic participation was constructed from student responses to a question asking whether they participated in in-school decision-making, debate organization, student council, and activities to improve the school environment, either by voting or running for office. From the descriptive data presented in Table 5.1, we can observe differences among Nordic countries and between them and the international mean of 50 in all scales in both 2009 and 2016. Although data were largely unchanged between 2009 and 2016, some small but significant changes did occur. There was a decrease in Denmark and an increase in Sweden in students' perceptions of open

Table 5.1 Descriptive statistics (mean and standard error) of the ICCS scales used in the analysis

\begin{tabular}{l|l|l|l|l|l|l}
\hline & Year & Denmark & Finland & Norway & Sweden & International $^{\wedge . *}$ \\
\hline \multirow{2}{*}{ Civic knowledge } & 2009 & $576(3.6)$ & $576(2.4)$ & $538(4.0)^{*}$ & $537(3.1)^{*}$ & $500(0.7)$ \\
\cline { 2 - 7 } & 2016 & $586(3.0)$ & $577(2.3)$ & $564(2.2)^{*}$ & $579(2.8)^{*}$ & $517(0.7)$ \\
\hline \multirow{2}{*}{$\begin{array}{l}\text { Open classroom } \\
\text { climate }\end{array}$} & 2009 & $55(0.3)^{*}$ & $49(0.2)$ & $53(0.5)$ & $51(0.3)^{*}$ & $50(0.1)$ \\
\cline { 2 - 7 } & 2016 & $54(0.3)^{*}$ & $49(0.2)$ & $52(0.3)$ & $52(0.4)^{*}$ & $50(0.1)$ \\
\hline $\begin{array}{l}\text { Students' } \\
\text { participation at } \\
\text { school }\end{array}$ & 2009 & $48(0.3)^{*}$ & $48(0.3)$ & $54(0.2)$ & $50(0.3)^{*}$ & $50(0.1)$ \\
\hline $\begin{array}{l}\text { Students'sense of } \\
\text { citizenship } \\
\text { self-efficacy }\end{array}$ & 2016 & $50(0.2)^{*}$ & $48(0.2)$ & $54(0.2)$ & $53(0.2)^{*}$ & $50(0.1)$ \\
\cline { 2 - 7 } & 2016 & $51(0.2)^{*}$ & $48(0.2)^{*}$ & $51(0.2)^{*}$ & $52(0.2)^{*}$ & $51(0.1)$ \\
\hline $\begin{array}{l}\text { Intended future } \\
\text { electoral } \\
\text { participation }\end{array}$ & 2009 & $49(0.2)^{*}$ & $49(0.2)^{*}$ & $52(0.3)^{*}$ & $49(0.3)^{*}$ & $50(0.1)$ \\
\cline { 2 - 7 } & 2016 & $52(0.2)^{*}$ & $51(0.2)^{*}$ & $54(0.1)^{*}$ & $53(0.2)^{*}$ & $51(0.1)$ \\
\hline
\end{tabular}

Notes All means are calculated by utilizing IDB Analyser and applying total student weight. * $p<$ 0.05 for differences between 2009 and 2016. ${ }^{\wedge}$ "Significance test was not performed as the number of countries participated in ICCS 2009 is different from that in ICCS 2016. School and Student level numbers are available in Chapter 1

\footnotetext{
${ }^{2}$ Chapter 1 of this book presents further details on the representative sample for each of the Nordic countries, including the number cases and schools per country.
} 
classroom climates, and there was an increase in students' in-school participation in Denmark and Sweden.

We included three measures of civic competence in our analysis: civic knowledge, citizenship self-efficacy, and intended future electoral participation with higher values indicating higher achievement of these scales. As discussed in the above section on civic competence, our measure of civic knowledge captures students' understanding and ability to apply knowledge in the four domains of: civic society and systems, civic principles, civic participation, and civic identities (Schulz et al. 2017). We measured civic knowledge using five plausible values using item-response-theory scaling to summarize student scores on test items. The other scales, all of which IEA had previously created, were derived from student responses to questions using item-response-theory weighted likelihood estimates (Köhler et al. 2018; Schulz et al. 2018). The scale of students' sense of citizenship self-efficacy was derived from a seven-item self report question asking how well they thought that they could follow, discuss, debate, and present to an in-school audience on social, political, or controversial issues, stand as representatives of student council, and write to a newspaper giving opinions on a current issue. The scale of students' intended future electoral participation was derived from their responses to a three-item question asking if they would vote in local or national elections as adults or get information about candidates before doing so. From the descriptive data presented in Table 5.1, we can observe some significant changes between 2009 and 2016 in the average student scores on items related to acquiring civic knowledge (increases in Norway and Sweden). There was also a Nordic-wide increase in students' sense of citizenship self-efficacy and intended future electoral participation.

To measure students' SES, we used the national index of socioeconomic backgrounds, which is a standardized score with an international/national mean of zero, a maximum value of 4.73 , and a minimum value of -5.27 . The national index is based on three indices: parents' highest occupational status, parents' highest level of education, and the number of books at home. We included students' gender (boy $=0$; girl $=1)$ and migrant status $(0=$ child and at least one parent were born in country; $1=$ student or both parents were migrants) as control variables (see Table 1.1 in Chapter 1 for the distributions of these variables).

To understand the levels of socioeconomic inequalities in civic competences, we used the national socioeconomic index variable to divide the ICCS data into four equal groups: students in lowest SES quantile, middle-lower SES quantile, middle-upper SES quantile, and highest SES quantile. Figure 5.1 provides a visual presentation of the average civic knowledge achievement of students in ICCS 2009 and 2016 by SES group and by country. Tests were performed to assess if differences between SES quantiles or changes over time (2009-2016) were significant. Figures 5.2 and 5.3 present these same parameters for citizenship self-efficacy and intended future electoral participation.

In analyzing the three measures of civic competence, a pattern emerged between the quintiles that showed that higher levels of SES corresponded to a higher level of 


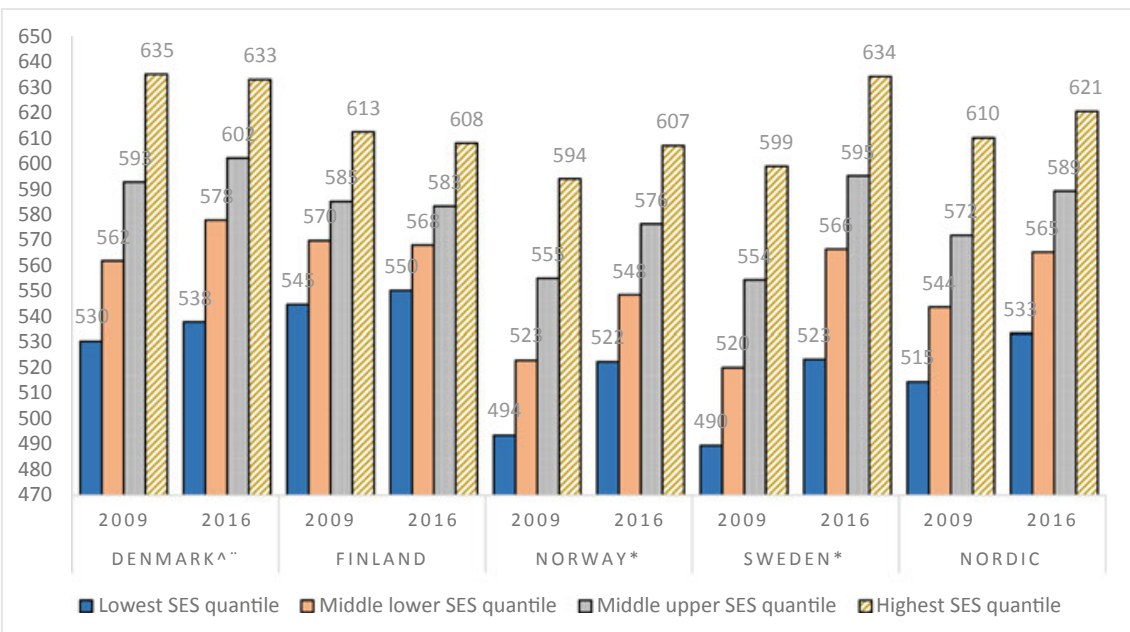

Fig. 5.1 Student civic knowledge achievement in four socio-economic strata and changes from ICCS 2009 and ICCS 2016, by country (Notes All means are calculated by utilizing IDB Analyzer on the five plausible values and applying total student weights. All differences between SES groups are significant unless notified otherwise. 'Difference between lowest SES quantile and middle lower SES quantile not significant; ^^difference between lowest SES quantile and middle lower SES quantile and difference between middle lower SES quantile and middle upper SES quantile not significant; ${ }^{*}$ changes from 2009 to 2016 are all significant except the group of highest SES quantile; ${ }^{\wedge} *$ changes from 2009 to 2016 are significant only for groups of middle lower and middle upper SES quantiles but not significant for the lowest SES and the highest SES quantiles; *all differences between all four SES groups were significant at each point of time, and changes from 2009 to 2016 were all significant)

civic competence. For civic knowledge (Fig. 5.1), differences between the quintiles were significant for all countries in both 2009 and 2016. The students with the highest level of citizenship self-efficacy (Fig. 5.2) for all four Nordic countries were the young people from the highest SES quintile. Differences between the lowest SES and middle-lower SES groups were not significant in Norway in 2009 or Sweden in 2009 and 2016. For intended future electoral participation (Fig. 5.3), the situation was almost the same, but the two middle quintiles in Finland in 2016 were not significantly different.

When we look for variations in inequality between countries, we saw that in the case of civic knowledge (Fig. 5.1), the distance between the lowest and highest SES quantiles was similar in Denmark (105 points in 2009 and 95 points in 2016), Norway (100 points in 2009 and 85 points in 2016), and Sweden (109 points in 2009 and 111 points in 2016) whilst the gap was smallest in Finland. Meanwhile, the gap was gradually narrowing in all countries expect Sweden. Regarding citizenship selfefficacy (Fig. 5.2), the inequality gap was similar in Denmark (5.7 points in 2009 and 4.7 points in 2016) and Sweden (5.7 points in 2009 and 3.9 points in 2016) with a significant decrease from 2009 to 2016 . While the gap in 2009 appeared smaller in Finland (4.2 points in 2009 and 4.7 points in 2016), and Norway (4.9 points in 


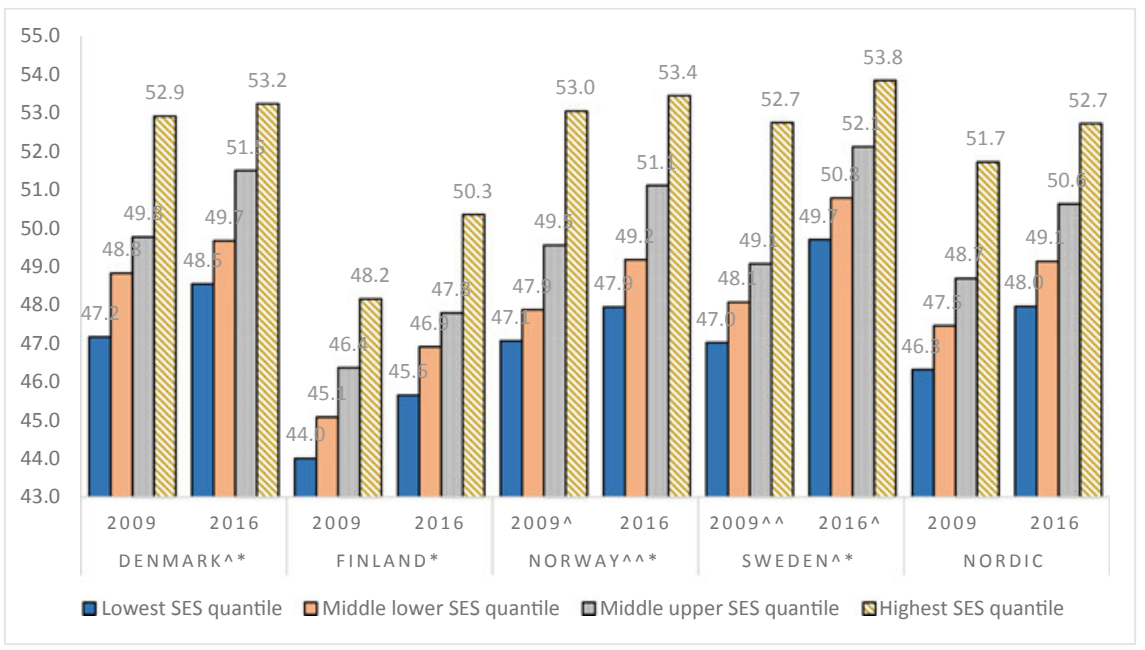

Fig. 5.2 Student citizenship self-efficacy in four socio-economic strata and changes from ICCS 2009 and ICCS 2016, by country (Notes All means are calculated by utilizing IDB Analyzer and applying total student weights. All differences between SES groups are significant unless notified otherwise. ^Difference between lowest SES quantile and middle lower SES quantile not significant; ^difference between lowest SES quantile and middle lower SES quantile and difference between middle lower SES quantile and middle upper SES quantile not significant; ${ }^{\wedge} *$ changes from 2009 to 2016 are all significant except the group of highest SES quantile; ${ }^{\wedge *}$ changes from 2009 to 2016 are significant only for groups of middle lower and middle upper SES quantiles but not significant for the lowest SES and the highest SES quantiles; *all differences between all four SES groups are significant and changes from 2009 to 2016 are significant for all SES groups)

2009 and 5.5 points in 2016) with some non-significant increase, the gap in Norway in 2016 became larger than that in other three countries. Regarding intended future electoral participation (Fig. 5.3), the differences between highest and lowest SES quintiles were similar in all countries (approx. 6.1-6.5 points in 2009 and 5.4-5.8 points in 2016) and in both studies except that the gap was largest in Norway both in 2009 (7.4 points) and in 2016 (6.7 points). Between 2009 to 2016, almost all SES groups in all four countries experienced significant increases in intended future electoral participation; the middle-upper SES quantile in Finland did not. 


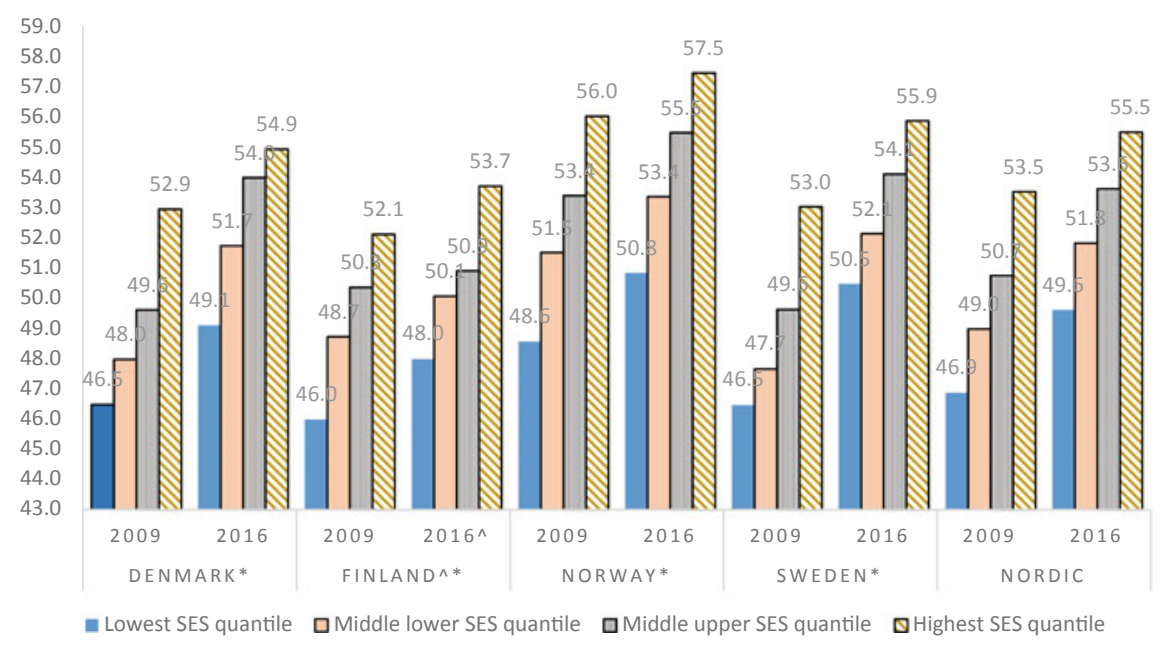

Fig. 5.3 Expected electoral participation when becoming adults of students in four socio-economic strata and changes from ICCS 2009 and ICCS 2016, by country (Notes All means are calculated by utilizing IDB Analyser and applying total student weight. All differences between SES groups are significant unless notified otherwise. *Changes of all four SES quantiles are significant from 2009 to 2016; 'difference between middle lower SES and middle upper SES quantiles is not significant; **changes from 2009 to 2016 are significant for all SES quantiles except middle upper SES quantile)

\subsection{Methods}

For the main analysis, we applied a multilevel regression analysis to simultaneously model the school-level (L2) and individual-level (L1) predictors of various outcomes. We first examined the extent to which access to civic learning was associated with SES by using the dependent variables of citizenship teaching methods: open classroom climates and in-school civic participation. We used the individual level (in this study this is referring to the individual student) and school-level variables of SES as our independent variables. Then, we used a multilevel regression analysis with interactions between SES and the two learning methods (open classroom climates and in-school civic participation) on civic competence (knowledge, citizenship selfefficacy, and intentions of future electoral participation). Studying the interaction between students' SES and civic learning opportunities enabled us to estimate the possible mitigating and accelerating effects of political learning experiences on civic competence. We will present the analysis results from random intercept models and by country so we can compare results between the four Nordic countries. We used Mplus (Muthén and Muthén 2012) to estimate the models, and we applied full information maximum likelihood estimators to include cases with missing data in some of the analysis variables. We also applied sampling weights by including student weights at individual-level (L1) and school weights at school level (L2) in our multilevel model testing in Mplus. 


\subsection{Results}

\subsubsection{Inequalities in Access to Civic Learning and Open Classroom Climates}

First, we estimated a null model to attribute the variance of the open classroom climate outcome to the individual and school levels. The analysis showed that roughly 5$15 \%$ of the variations of experiences of open classroom climates could be accounted for by differences between schools. Finland had the lowest, with a variation of $6.3 \%$ between schools in 2016. Denmark had about $16 \%$ in both cycles. These results suggest that there is a difference between schools in Denmark in terms of the student experience of open classroom climate but in Finland differences between schools are negligible.

Second, we added the SES of students at the individual level and the average SES of students attending a school (school intake) at the school level to the model. The purpose of this was to understand whether students from different schools reported different levels of open classroom climate and to test if that level was higher in classrooms composed of students with higher SES.

At the individual level, students' SES had a significant positive relationship with their experience of access to an open classroom climate in Denmark, Norway, and Sweden in 2009 and 2016 (see Table 5.2). This suggests that for these countries, the higher the social class, the more students felt that the classroom was open and that they were able to participate in class discussions. Surprisingly, Norway had the largest regression parameters for SES on perceived openness of classroom climate in 2016. In Finland, the interaction was not significant in 2009 or 2016, suggesting that SES does not have to limit students' experience of access to an open classroom climate. In general, there were few changes between the studies, but an increase in the parameters of Sweden and a decrease in those of Denmark can be seen. The explained variance of the model at the individual level was very low (1-3\%).

Despite there only being a small amount of variation between schools, SES appears to be a more important variable in explaining the variation at the school level than at the individual level. At the school level in Denmark and Sweden, the relationship between the SES of the school's student intake was significantly related to open classroom climate in 2009 and 2016 (see Table 5.2). This indicates that in Denmark and Sweden, the higher the average social class of the students attending the school, the more likely it was that the they reported access to open classroom climates, implying that there were differences between schools in the methods used in classrooms according to the SES level in the school's intake. In 2009, the regression parameter was significant in Norway, though it was no longer so in 2016. In contrast, in Finland, school-level SES increased and became significant in 2016, suggesting that inequalities in students' experiences between schools were starting to appear. The explained variance at the school level in 2016 was high in Denmark, at 28\%; in Finland and Sweden, it was about $14 \%$. In Norway, it was $4 \%$. 


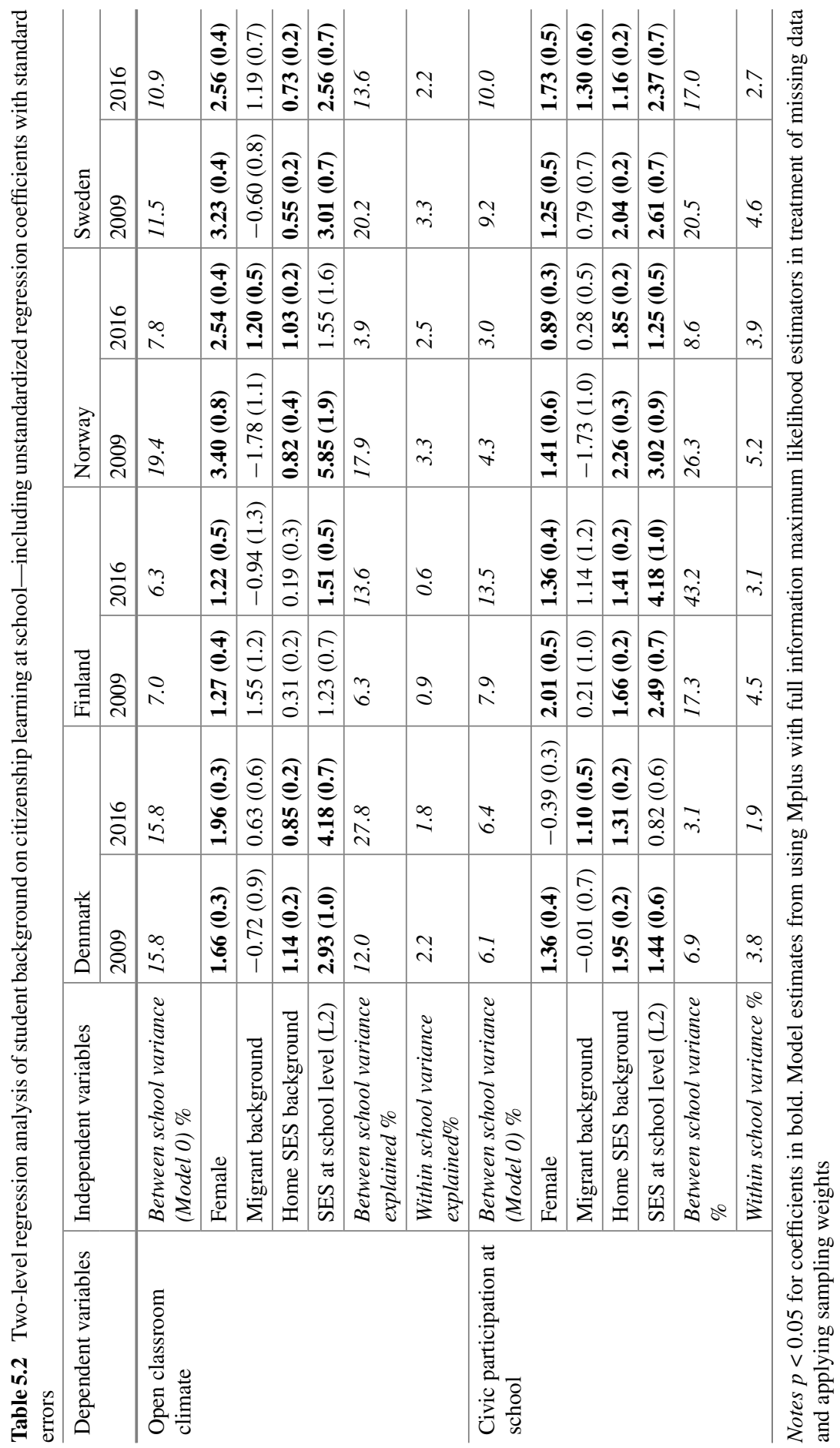




\subsubsection{In-School Civic Participation}

As with an open classroom climate, the first step in our analysis of in-school civic participation was to estimate a null model and attribute the variance of the outcome in-school civic participation to the student and school levels. The null model showed that the between school variance was very small in Norway (4.3\% in 2009 and 3\% in 2016), the highest level and with the highest increase was Finland (7.9\% in 2009 and $13.5 \%$ in 2016) and then Sweden (9.2\% in 2009 and $10 \%$ in 2016) while it was small and stable in Denmark (6.1\% in 2009 and 6.4\% in 2016).

Second, we added the socioeconomic status of students and the average socioeconomic status of the school intake (school level) to the model to study whether students from different schools reported different levels of in-school civic participation and to test if the amount of participation was higher in schools composed of students with higher SES.

At the individual level, there was a significant positive relationship between students' SES and in-school civic participation across all Nordic countries in 2009 and 2016 (see Table 5.2). This suggested that in all Nordic countries, social class may well influence access to in-school civic participation. In 2016, the regression parameter of SES at individual level were largest in Norway (2.26) and smallest in Sweden (1.16). Between 2009 and 2016, the parameters were reduced in all Nordic countries, suggesting a reduction in inequalities related to in-school civic participation. The explained variance at the individual level was low (2-5\%).

The variation among schools can be partly explained by the SES level of the student intake. In Finland, Norway, and Sweden in 2009 and 2016, we found differences between schools concerning access to in-school civic participation according to the SES intake of the school. For these countries we found that there were more inschool civic participation activities in schools that had more high-level-SES students. In Denmark, this was not the case in 2016. The explained variance of the school level differences appears quite varied, for example, for Finland in 2016 it is $43 \%$ and in Denmark in 2016 it is only $3.3 \%$. It is important to note, however, that the amount of variance explained between schools relates to the size of the null model-how much variation there actually is between schools. This means that although these differences can look large they are actually much less dramatic. For example, in 2009 the Finnish model on in-school civic participation explained $43 \%$ of the $13.5 \%$ variation that exists between schools that equates to $3.2 \%$ of the overall variation of students in-school civic participation. In contrast, the Danish model in 2009 where there was only $6.9 \%$ explained variance was actually explaining the $6.1 \%$ of variation that was existing between schools in Denmark in 2009 and that the $6.9 \%$ actually equates to $1.1 \%$ of the overall variation in in-school civic participation of Danish students.

We recognize that different experiences among students in schools and between schools according to the socioeconomic backgrounds of the students are not the only explanation for differing levels of civic competence-for example, the learning in the home environment is also very important for developing civic competences. Nevertheless, our results suggest that schooling in the Nordic education system, 
as in the English education system (Hoskins and Janmaat 2019), is playing a role in limiting access based on student SES to two important ways of civic learning (in-school civic participation and open classroom climate) in all Nordic countries.

\subsubsection{Learning Civic Competence}

The importance of access to civic learning becomes clear when we look at the relationship of these forms of learning with different dimensions of civic competence. The results of our multilevel regression analysis are presented in Tables 5.3 and 5.4. First, we estimated a null model to attribute the variance in the outcome of each of the three aspects of civic competence (civic knowledge, citizenship self-efficacy, and intended future electoral participation) to the student and school levels. The level of variation between schools explains between 11 and $17 \%$ of the variations in the civic knowledge scores of students in Sweden and Denmark (see Table 5.3). In 2016 in Finland and Norway, it was only 6\%. For citizenship self-efficacy and intended future electoral participation scores, there was very little variation explained at the school level (see Table 5.4). Citizenship self-efficacy ranged between 2\% and 5\%, while intended future electoral participation ranged between $5 \%$ and $10 \%$, except for Norway in 2016, when it was 3.4\%.

Second, we added the civic learning variables (open classroom climates and inschool civic participation), the socioeconomic status of students (at the individual and the school level), and the interaction variables between the individual-level socioeconomic status and individual-level civic learning opportunities in order to identify mitigating or accelerating effects.

At the individual level, there was a direct and significant relationship between both forms of civic learning opportunities (open classroom climates and in-school civic participation) on each of the three aspects of civic competence in all Nordic countries in both 2009 and 2016. This adds further compelling evidence of the importance of these methodologies in learning civic competence to the already-significant literature in the field (e.g., Campbell 2008; Hahn 1998; Hoskins et al. 2012; Keating and Janmaat 2016; Knowles et al. 2018; Quintelier and Hooghe 2012; Torney-Purta 2002).

Understanding the extent of the importance of students' peers' experiences (open classroom climates and in-school civic participation) on an individual student's civic learning was more complex. When comparing the school and the individual level effects on civic knowledge (see Table 5.3), individual experiences of civic learning stood out more than the collective student experience. This could be seen in our models, which showed that the school-level forms of participatory learning appeared to be less important in explaining differences in civic knowledge. The mean level of peers' civic participation had almost no significant relationships with civic knowledge (the exception here was a significant positive result for Sweden in 2016). The mean level of open classroom climate on civic knowledge had a significant and positive relationship in half of our results. A consistent significant relationship was 
Table 5.3 Two-level regression analysis of student background and school learning factors on student civic knowledge achievement—including unstandardized coefficient with standard errors

\begin{tabular}{|c|c|c|c|c|c|c|c|c|}
\hline \multirow{2}{*}{$\begin{array}{l}\text { Independent } \\
\text { variables }\end{array}$} & \multicolumn{2}{|c|}{ Denmark } & \multicolumn{2}{|l|}{ Finland } & \multicolumn{2}{|l|}{ Norway } & \multicolumn{2}{|l|}{ Sweden } \\
\hline & 2009 & 2016 & 2009 & 2016 & 2009 & 2016 & 2009 & 2016 \\
\hline $\begin{array}{l}\text { School } \\
\text { variance } \\
\text { (Model 0) \% }\end{array}$ & 16.4 & 17.3 & 9.3 & 6.0 & 13.7 & 5.6 & 16.9 & 11.4 \\
\hline Female & $\begin{array}{l}2.83 \\
(3.1)\end{array}$ & $\begin{array}{l}17.97 \\
(2.7)\end{array}$ & $\begin{array}{l}23.53 \\
(4.1)\end{array}$ & $\begin{array}{l}\text { 30.76 } \\
\text { (3.9) }\end{array}$ & $\begin{array}{l}13.88 \\
(4.5)\end{array}$ & $\begin{array}{l}25.43 \\
(2.9)\end{array}$ & $\begin{array}{l}11.87 \\
(4.7)\end{array}$ & $\begin{array}{l}28.80 \\
(4.5)\end{array}$ \\
\hline $\begin{array}{l}\text { Migrant } \\
\text { background }\end{array}$ & $\begin{array}{l}-37.89 \\
(7.4)\end{array}$ & $\begin{array}{l}-29.43 \\
(5.8)\end{array}$ & $\begin{array}{l}-\mathbf{5 1 . 1 3} \\
\mathbf{( 1 1 . 0 )}\end{array}$ & $\begin{array}{l}-71.72 \\
(10.4)\end{array}$ & $\begin{array}{l}-40.40 \\
(8.6)\end{array}$ & $\begin{array}{l}-47.03 \\
(5.1)\end{array}$ & $\begin{array}{l}-35.07 \\
(6.4)\end{array}$ & $\begin{array}{l}-51.40 \\
(6.3)\end{array}$ \\
\hline $\begin{array}{l}\text { Home SES } \\
\text { background }\end{array}$ & $\begin{array}{l}36.16 \\
(8.3)\end{array}$ & $\begin{array}{l}27.02 \\
(7.3)\end{array}$ & $\begin{array}{l}34.46 \\
(12.2)\end{array}$ & $\begin{array}{l}37.07 \\
(12.2)\end{array}$ & $\begin{array}{l}42.20 \\
(22.7)\end{array}$ & $\begin{array}{l}45.38 \\
(16.0)\end{array}$ & $\begin{array}{l}39.97 \\
(12.6)\end{array}$ & $\begin{array}{l}39.66 \\
(21.35)\end{array}$ \\
\hline $\begin{array}{l}\text { Open } \\
\text { classroom } \\
\text { climate }\end{array}$ & $\begin{array}{l}1.66 \\
(0.2)\end{array}$ & $\begin{array}{l}1.87 \\
(0.1)\end{array}$ & $\begin{array}{l}0.43 \\
(0.2)\end{array}$ & $\begin{array}{l}1.05 \\
(0.3)\end{array}$ & $\begin{array}{l}1.91 \\
(0.3)\end{array}$ & $\begin{array}{l}1.22 \\
(0.2)\end{array}$ & $\begin{array}{l}1.32 \\
(0.3)\end{array}$ & $\begin{array}{l}1.33 \\
(0.2)\end{array}$ \\
\hline $\begin{array}{l}\text { Civic } \\
\text { participation } \\
\text { at school }\end{array}$ & $\begin{array}{l}1.83 \\
(0.2)\end{array}$ & $\begin{array}{l}0.97 \\
(0.2)\end{array}$ & $\begin{array}{l}1.40 \\
(0.2)\end{array}$ & $\begin{array}{l}1.11 \\
(0.3)\end{array}$ & $\begin{array}{l}2.03 \\
(0.3)\end{array}$ & $\begin{array}{l}1.45 \\
(0.2)\end{array}$ & $\begin{array}{l}1.84 \\
(0.2)\end{array}$ & $\begin{array}{l}1.85 \\
(0.3)\end{array}$ \\
\hline $\begin{array}{l}\text { SES*Open } \\
\text { classroom }\end{array}$ & $\begin{array}{l}-0.19 \\
(0.2) \\
\end{array}$ & $\begin{array}{l}0.00 \\
(0.1)\end{array}$ & $\begin{array}{l}0.20 \\
(0.3) \\
\end{array}$ & $\begin{array}{l}-0.25 \\
(0.3) \\
\end{array}$ & $\begin{array}{l}0.16 \\
(0.5) \\
\end{array}$ & $\begin{array}{l}-0.14 \\
(0.3) \\
\end{array}$ & $\begin{array}{l}-0.24 \\
(0.2) \\
\end{array}$ & $\begin{array}{l}-0.20 \\
(0.3) \\
\end{array}$ \\
\hline $\begin{array}{l}\text { SES*Civic } \\
\text { participation } \\
\text { at school }\end{array}$ & $\begin{array}{l}0.01 \\
(0.2)\end{array}$ & $\begin{array}{l}-0.05 \\
(0.1)\end{array}$ & $\begin{array}{l}-0.41 \\
(0.16)\end{array}$ & $\begin{array}{l}-0.10 \\
(0.2)\end{array}$ & $\begin{array}{l}-0.53 \\
(0.3)\end{array}$ & $\begin{array}{l}-0.30 \\
(0.3)\end{array}$ & $\begin{array}{l}0.03 \\
(0.2)\end{array}$ & $\begin{array}{l}-0.02 \\
(0.3)\end{array}$ \\
\hline $\begin{array}{l}\text { SES at } \\
\text { school level } \\
\text { (L2) }\end{array}$ & $\begin{array}{l}63.84 \\
(6.9)\end{array}$ & $\begin{array}{l}50.83 \\
(6.4)\end{array}$ & $\begin{array}{l}22.51 \\
(7.2)\end{array}$ & $\begin{array}{l}22.50 \\
(6.9)\end{array}$ & $\begin{array}{l}\mathbf{5 3 . 5 0} \\
(10.7)\end{array}$ & $\begin{array}{l}40.84 \\
(5.2)\end{array}$ & $\begin{array}{l}62.96 \\
(5.9)\end{array}$ & $\begin{array}{l}\mathbf{5 8 . 2 0} \\
(\mathbf{7 . 2 )}\end{array}$ \\
\hline $\begin{array}{l}\text { Open } \\
\text { classroom } \\
\text { climate (L2) }\end{array}$ & $\begin{array}{l}1.92 \\
(0.7)\end{array}$ & $\begin{array}{l}2.76 \\
(0.7)\end{array}$ & $\begin{array}{l}2.94 \\
(1.0)\end{array}$ & $\begin{array}{l}0.37 \\
(1.0)\end{array}$ & $\begin{array}{l}2.38 \\
(0.8)\end{array}$ & $\begin{array}{l}1.30 \\
(0.8)\end{array}$ & $\begin{array}{l}3.44 \\
(0.7)\end{array}$ & $\begin{array}{l}1.42 \\
(0.73)\end{array}$ \\
\hline $\begin{array}{l}\text { Civic } \\
\text { participation } \\
\text { at school } \\
\text { (L2) }\end{array}$ & $\begin{array}{l}0.05 \\
(0.9)\end{array}$ & $\begin{array}{l}-0.63 \\
(0.9)\end{array}$ & $\begin{array}{l}-0.45 \\
(0.8)\end{array}$ & $\begin{array}{l}0.93 \\
(1.0)\end{array}$ & $\begin{array}{l}2.22 \\
(1.4)\end{array}$ & $\begin{array}{l}2.23 \\
(1.2)\end{array}$ & $\begin{array}{l}-0.90 \\
(1.0)\end{array}$ & $\begin{array}{l}1.77 \\
(0.7)\end{array}$ \\
\hline $\begin{array}{l}\text { Between } \\
\text { variance } \\
\text { explained \% }\end{array}$ & 62.6 & 66.1 & 24.4 & 43.0 & 67.7 & 66.4 & 75.7 & 85.7 \\
\hline $\begin{array}{l}\text { Within } \\
\text { variance } \\
\text { explained \% }\end{array}$ & 21.6 & 14.9 & 25.7 & 25.0 & 31.0 & 30.3 & 22.7 & 25.0 \\
\hline
\end{tabular}

Notes Model estimates from using Mplus with full information maximum likelihood estimators in treatment of missing data, applying sampling weights and using all five plausible values. $p<0.05$ for coefficients in bold 
5 Socioeconomic Inequalities in Civic Learning ...

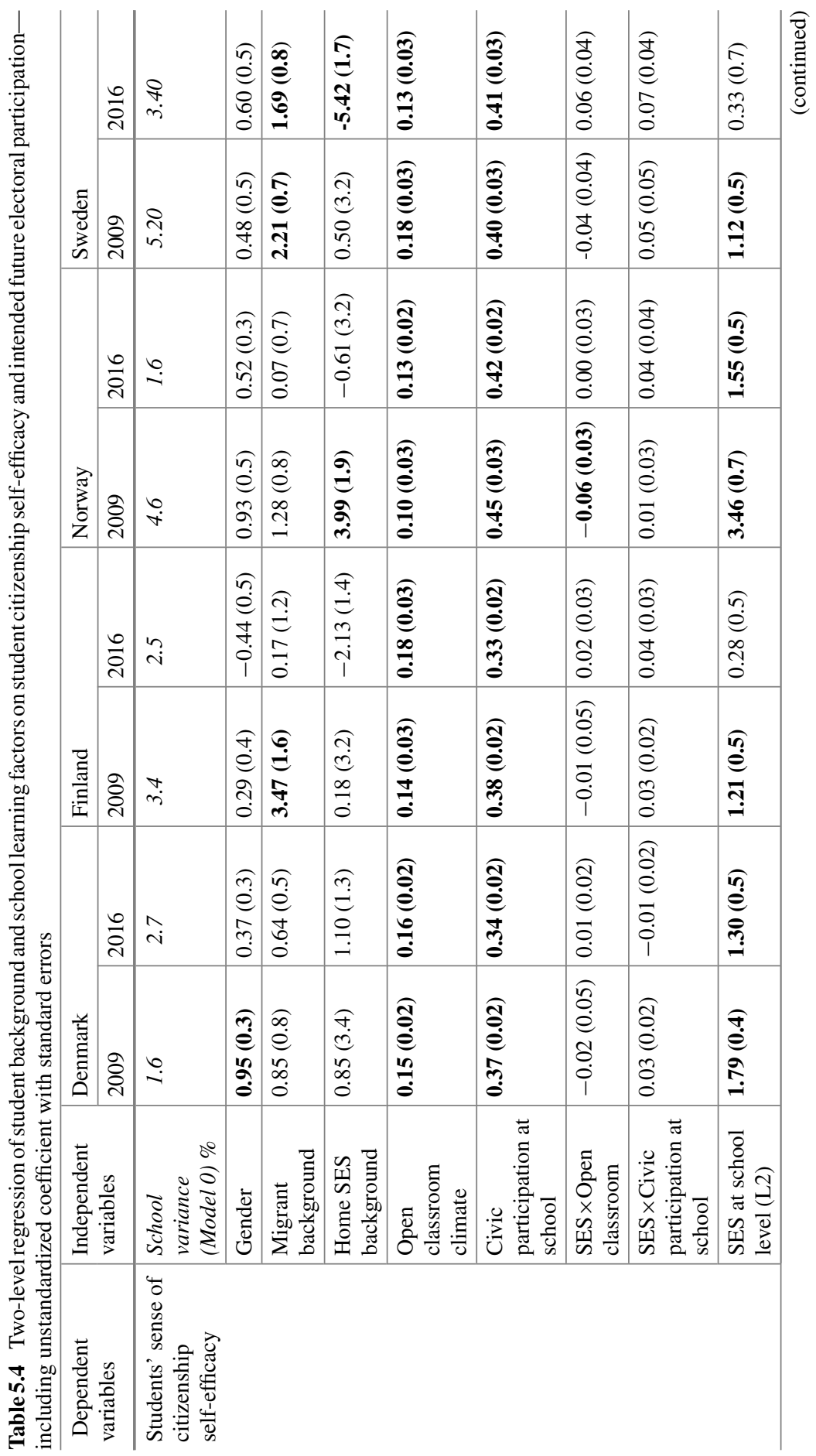




\begin{tabular}{|c|c|c|c|c|c|c|c|c|c|}
\hline & $\stackrel{0}{\Xi}$ & 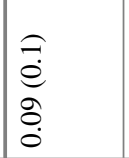 & 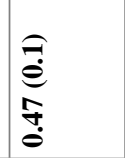 & $\frac{n}{\pi}$ & $\vec{m}$ & $\dddot{n}$ & 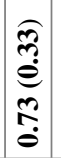 & 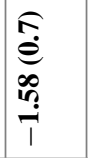 & $\begin{array}{l}\stackrel{6}{\leftrightarrows} \\
\stackrel{5}{\circ}\end{array}$ \\
\hline & 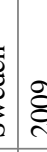 & 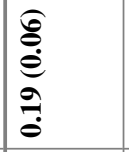 & 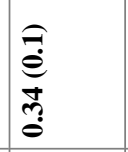 & 3 & $\stackrel{\infty}{\grave{\sim}}$ & $\infty$ & 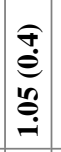 & $\begin{array}{l}0 \\
0 \\
0 \\
\infty \\
0 \\
0 \\
0\end{array}$ & 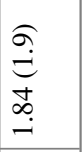 \\
\hline & 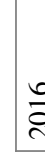 & 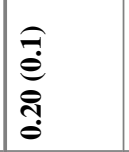 & 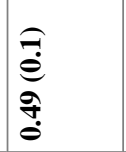 & $\frac{n}{\infty}$ & $\check{6}$ & $\ddot{r}$ & 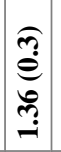 & 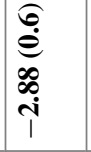 & 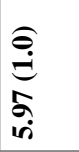 \\
\hline & 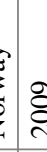 & $\begin{array}{l}0 \\
0 \\
0 \\
0 \\
0\end{array}$ & 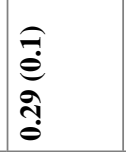 & 8 & $\stackrel{\nabla}{\check{n}}$ & $\begin{array}{l}\infty \\
0 \\
0\end{array}$ & $\begin{array}{l}0 \\
0 \\
e \\
0 \\
\vdots \\
0\end{array}$ & 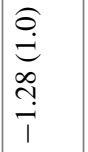 & $\frac{\substack{n \\
ٍ}}{\sqrt[n]{6}}$ \\
\hline & c & 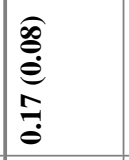 & 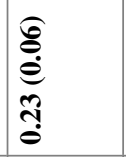 & in & $\frac{n}{\pi}$ & $\stackrel{\Upsilon}{N}$ & 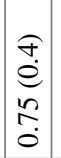 & 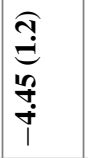 & 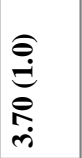 \\
\hline & 8 & 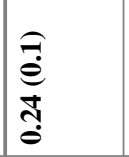 & 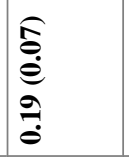 & \begin{tabular}{l}
$a$ \\
$\infty$ \\
\multirow{\sigma}{*}{}
\end{tabular} & $\stackrel{n}{\cong}$ & $\stackrel{b}{\forall}$ & $\begin{array}{c}\hat{f} \\
\tilde{e} \\
m \\
\tilde{o} \\
0\end{array}$ & 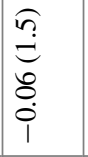 & 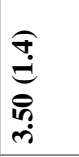 \\
\hline & $\stackrel{\sigma}{c}$ & 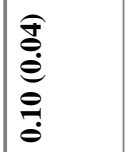 & 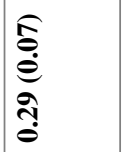 & $\underset{x}{N}$ & $\stackrel{\text { İ }}{2}$ & $\vec{\infty}^{\infty}$ & 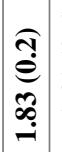 & 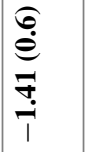 & 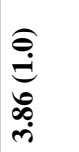 \\
\hline & है & 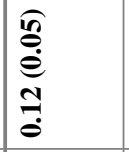 & 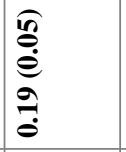 & $\stackrel{n}{n}$ & $\stackrel{7}{2}$ & $\begin{array}{l}\infty \\
\forall\end{array}$ & 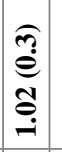 & 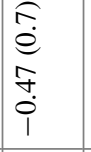 & 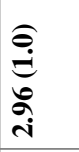 \\
\hline & 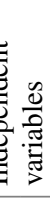 & 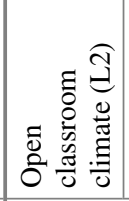 & 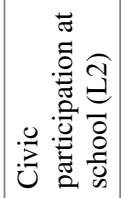 & 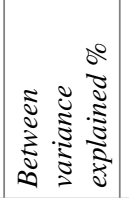 & 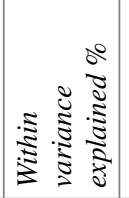 & 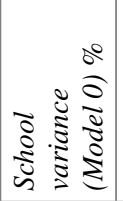 & 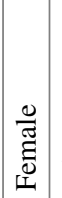 & 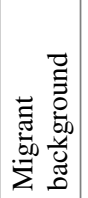 & 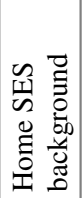 \\
\hline & 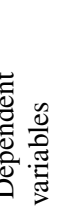 & & & & & 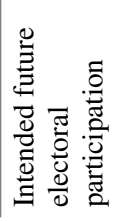 & & & \\
\hline
\end{tabular}


5 Socioeconomic Inequalities in Civic Learning ...

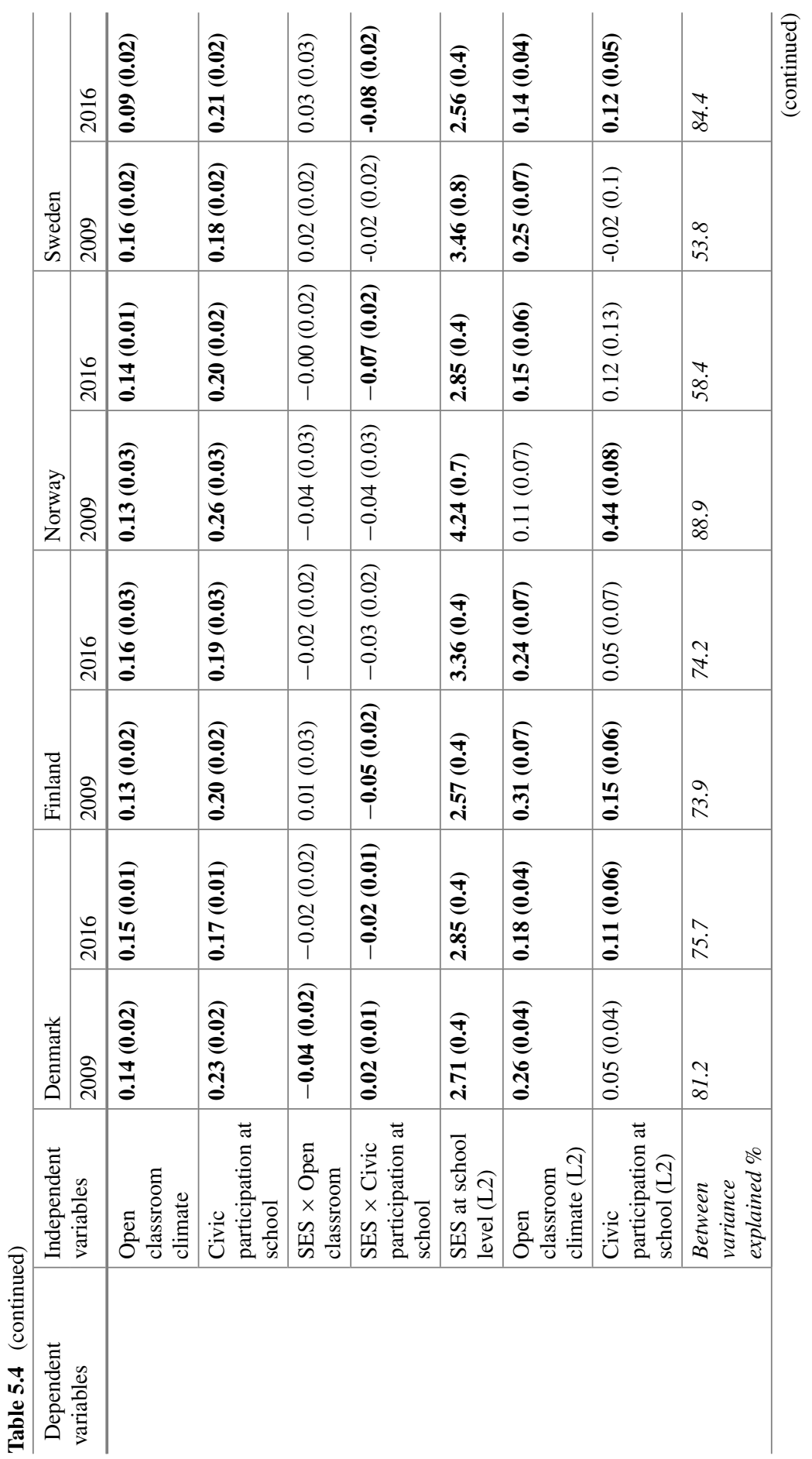




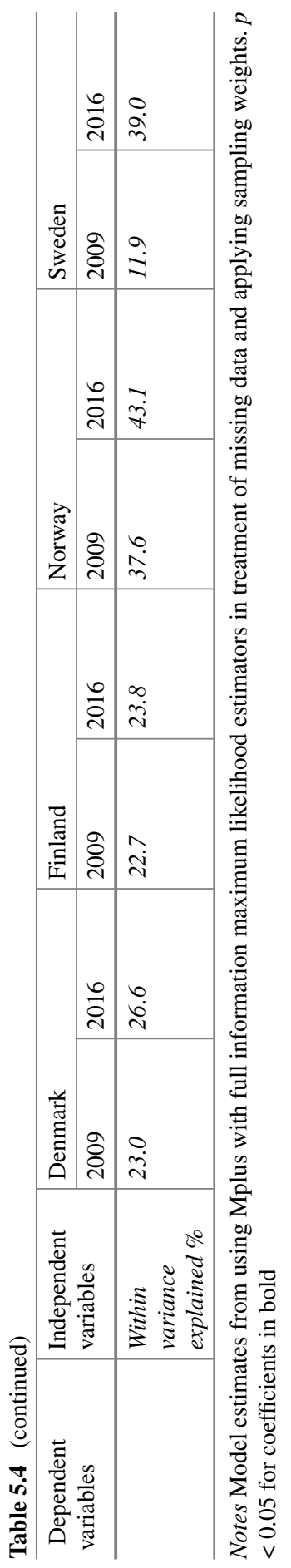


only found in Denmark. This suggests that an inclusive student experience of an open classroom climate for the whole class were important to the development of civic knowledge only in certain education contexts.

In contrast to civic knowledge, peer's learning experiences appear to be important in the learning of citizenship self-efficacy. The results show that the mean level of peers' civic participation at school consistently appears to be supporting the individual students' learning of citizenship self-efficacy (see Table 5.4), as the results were significant and positive for each Nordic country in both studies. Thus, it appeared important to a students' citizenship efficacy that their peers were also involved in in-school civic participation; we can call this a participatory school community. For citizenship self-efficacy, there was also a fair amount of evidence for the benefits of wider and more inclusive open classroom climates that could be experienced by most students, as the vast majority (six of eight) of results showed a significant positive relationship (except for Norway in 2009 and Sweden in 2016).

For intended future electoral participation, the experience of the school-level mean of open classroom climate had positive significant coefficients (see Table 5.4) for all Nordic countries in both studies (except for Norway in 2009). This suggests that an inclusive classroom could be an important component in students' developing of their intentions to vote. There was a mixed picture, with four out of eight results suggesting a relationship between school-level civic participation and future electoral participation. It remains unclear why school-level civic participation was less consistently associated with students' future electoral participation than it was for developing citizenship self-efficacy.

\subsubsection{Direct Effects of SES on Civic Competence}

We will now examine the direct relationship between SES and levels of civic competence (please note that we controlled for the learning methods; see Tables 5.3 and 5.4). The results showed a consistent significant relationship between SES and levels of civic knowledge for all Nordic countries in both studies. The coefficient was highest in Norway, where a one standard deviation increase in SES was equal to a 42-point increase in 2009 and a 45-point increase in 2016 in students' civic knowledge scores. For Sweden in 2016, the increase was 40 points. For Finland, in 2016 it was 37 points. For Denmark in 2016, it was considerably lower at 27 points.

The relationship between SES and intended future electoral participation was similar to civic knowledge as there were nearly all consistent significant positive coefficients in all four countries in both studies (the exception was Sweden in 2009). In 2016, Norway had the largest size coefficient (5.97), followed by Sweden (4.07), Denmark (3.86), and Finland (3.70).

In contrast, there was less evidence to support the existence of a direct relationship between SES on levels of citizenship self-efficacy as the results were only significant in 2016 in Sweden and 2009 in Norway. Instead, our results indicate the possibility that the relationship between the SES index and citizenship self-efficacy 
could perhaps be more indirect and through the significant relationship of SES on students' experience of learning opportunities such as open classroom climate and in-school civic participation (see Table 5.2) which then in turn may have a significant direct influence on citizenship self-efficacy both at the individual student and school levels (Table 5.4).

The relationship between the socioeconomic student intake of the school (mean level) and civic competence was clearer. In referring to Tables 5.3 and 5.4, we can see that there were consistently large and significant coefficients for civic knowledge according to the socioeconomic student intake of schools in all four countries in both studies. This suggests that schools with higher socioeconomic intakes were more focused on developing students' levels of civic knowledge than schools with lower socioeconomic intakes. For civic knowledge in 2016, the results had the largest association in Sweden, where a one standard deviation increase in the average socioeconomic intake of a school resulted in a staggering 58-point increase in an individual student's civic knowledge score. We found similar results for the relationship between the school's socioeconomic intakes and future electoral participation, and this was mostly the case for citizenship self-efficacy (the exception was Finland and Sweden in 2016).

\subsubsection{Compensatory or Accelerating Effects}

Finally, we considered the possibility that a civic learning experience can compensate for a disadvantaged background by examining the results of the interaction between SES and the three aspects of civic competence (see Tables 5.3 and 5.4). The literature in the field identifies that a significant negative result suggested a compensatory effect, while a significant positive result suggested an acceleration effect (Campbell 2008). The results showed that there were almost no significant positive results indicating that there were almost no evidence that levels of inequalities in future political engagement were being enhanced by participating in a civic learning experience. The one exception is for Denmark in 2009 where there was a small (0.02) significant accelerating effect for in-school civic participation on future electorial participation. Thus, in the main our analysis showed that once a student accessed civic learning, there was little in the way of evidence that these experiences by themselves made inequalities in civic competence worse.

Further, we can report that we found seven significant negative coefficients that indicate that civic learning can compensate for low SES backgrounds. In Table 5.4, we can see the results of the interactions between SES and civic participation at school on future electoral participation, and four of the coefficients had a small but significant negative result and this was in 2016 for Denmark $(-0.02)$, Norway $(-0.07)$, and Sweden $(-0.08)$ and in 2009 for Finland (-0.05). This can be interpreted as indicating that students from disadvantaged backgrounds benefited more from civic participation in schools in Denmark, Norway, and Sweden in 2016 and in Finland in 2009 in terms of improving their levels of intended future electoral participation. 
These results suggest that students from a disadvantaged background who were able to access in-school civic participation were able to learn more about the importance of voting from undertaking this experience than those from more privileged backgrounds who were engaged in these same activities. Although the Danish results were the smallest they had managed to change from a significant accelerating effect to a significant mitigating effect between the two time points.

In Finland in 2009, participation in in-school civic participation was also found to compensate for low SES on students' learning of civic knowledge (-0.41). This was the largest mitigating effect that we found, and it stands out in comparison to the small effects found in the literature (Hoskins and Janmaat 2019).

In more cases than not, the individual experience of an open classroom climate had the same benefit for each student regardless of their SES. Nevertheless, there were two cases where a small mitigating effect was found. The experience of an open classroom climate in 2009 reduced inequalities in citizenship self-efficacy in Norway (-0.06) and in future electoral participation in Denmark $(-0.04)$.

\subsubsection{Explained Variance of the Models}

Regarding civic knowledge at the individual level, our model explained 15-31\% of the variation. The model worked particularly well in Norway, with consistently 30 $31 \%$ of the variation being explained in both studies. Our models measured a high level of explained variance at the school level, ranging from about $25 \%$ in Finland to $86 \%$ in Sweden.

For citizenship self-efficacy, our model explained 15-35\% of individual-level variation. The model worked particularly well at the individual level in Sweden in 2016, explaining 35\% of individual level variation. The school-level variables in our model explained $49-81 \%$ of school-level variation. Norway was the country where the model was able to explain $81 \%$ of the explained variance.

For future electoral participation, the model explained a substantial amount of the variance at the individual level, mostly between 23 and 43\%. Here, the model worked particularly well in Norway in 2016, accounting for $43 \%$ of the individuallevel variations. Our model explained a large degree of school-level variation, ranging between 54 and 89\%. Again, in Norway, the model fit well and explained just shy of $90 \%$ of variations among schools.

\subsection{Discussion and Conclusion}

Before beginning the discussion, it is necessary to note that in contrast with Hoskins and Janmaat's (2019) longitudinal research, the research used in this chapter was only based on cross-sectional data from the IEA ICCS, meaning it is necessary to be cautious regarding causality and effects, and it also necessary to understand the results 
as exploratory. Additionally, the learning experiences and attitude measures were self-reported by students, which means deliberately incorrect or desirable responses could have been provided. Nevertheless, the quality and representative nature of the data collected by IEA are internationally regarded as meeting a very high standard. Further, being able to replicate the analysis in each Nordic country over the course of two studies helped provide assurance regarding the certainty of the results.

Even when taking these cautionary principles into account, we found substantial evidence suggesting that schools may well influence socioeconomic inequalities in civic competence in Nordic countries. Much as in the United Kingdom, the issue of access is key. We found evidence that disadvantaged students comparatively to socioeconomic advantaged students experience a lack of in-school access to civic learning in all Nordic countries. Concerning civic participation in schools, Hoskins and Janmaat (2019) argued convincingly that this is often a result of the voluntary nature of these activities in schools, and middle-class students are more likely to volunteer and be asked by the teacher to participate because of their higher levels of cultural capital. Social class distinctions and conflict begin also to explain differences in the perception of how open a classroom is for discussion. Nevertheless, how social class manifests itself in Nordic schools requires more research.

In addition to access-related differences within schools, there is also a difference in access to and opportunities for civic learning between schools. Our results suggested that the much-applauded Nordic comprehensive education system is not as equal as presented within its policies. This chapter's evidence points towards schools with higher socioeconomic student intake as hosting more in-school civic activities and having more classrooms that are open to discussion (except Norway in 2016 regarding open classroom climates and Denmark in 2016 regarding civic participation). It is true that between schools, differences are not that high in Nordic countries compared to that of the rest of the world (as was demonstrated by the low levels of betweenschool variations). Nevertheless, the evidence suggests that schools are now teaching differently according to their socioeconomic student intakes. We can hypothesize that Nordic schools may now also be influenced by neoliberal arguments for the need for schools with low socioeconomic student intakes to prioritize basic skills and the passing of tests; they may also be influenced by the belief that these outcomes are achieved in schools by keeping stricter order rather than prizing open discussion (Ben-Porath 2013; Bischoff 2016).

The results also showed that socioeconomic inequalities have a strong, direct, and additional relationship with levels of civic knowledge and future electoral participation. The higher the SES, the higher the levels of these civic competences. As our data are not longitudinal, fully explaining this process is difficult. Nevertheless, based on the literature in the field (Hoskins and Janmaat 2019), we can speculate that these effects are partly due to additional learning at home in the context of families with high SES who are more likely to openly discuss family decisions and politics and also act as role models participating in political activities.

We also found large between-school differences in civic competence based on socioeconomic student intakes. We controlled for our civic learning variables at the school level, meaning that the explanation cannot relate to more open classroom 
discussion or more participation in civic activities at school. These effects could be due to more or better citizenship education at these schools, or it could be due to students learning from each other about civic competences. Further research is needed to be certain which is the more likely explanation.

\subsubsection{A Nordic Model of Inequalities in Civic Learning?}

Although the issue of inequalities in access to civic learning are apparent in all Nordic countries, it did not manifest in the same way in each. Due to the introduction of several neoliberal reforms, we had suspected that Sweden would be the most unequal of all Nordic countries regarding inequalities in civic learning. There is some evidence to support this. The Swedish results indicated inequalities in access to both forms of civic learning at the individual and school levels in 2009 and 2016, and Sweden was the only country that identified inequalities across the board on the question of access. Sweden had socioeconomic inequalities at the individual level in 2016 for all three forms of civic competence, including citizenship self-efficacy (which was not the case for the remaining Nordic countries in 2016). Sweden had the highest differences between schools on civic knowledge scores in which a one standard deviation increase in a school's average socioeconomic student intake resulted in a staggering 58-point increase in an individual student's civic knowledge score.

Finland, which we had expected to have the most equal education system of the Nordic countries, had no socioeconomic inequalities related to access to open classroom climate at the individual level and regularly had one of the lower effects compared to other Nordic countries. In 2016, Norway was another example of equality in the learning of civic competences, as its education system achieved socioeconomic equality between schools regarding the levels of open classroom climates. In 2016, Denmark enabled civic participation equality between schools. The fact that these countries managed to attain equality of students' experience of civic learning regardless of SES is an important reminder for all education systems: it is possible to achieve this.

Nevertheless, the results did not fit neatly into the boxes of expected socioeconomic inequalities in the education systems of the different countries. All four countries experienced an individual direct relationship between SES and civic knowledge, future electoral participation, and inequality of access to in-school civic participation. Finland had both school- and individual-level inequalities regarding access to in-school civic participation. Additionally, the evidence points to Norway as having the highest individual level inequality of access to open classroom climate and inschool civic participation. When it came to the direct relationship between socioeconomic inequalities in levels of civic competence, Norway again had the largest individual-level relationship. For example, in 2016, a one standard deviation increase in a students' SES was equal to a 45-point increase in their civic knowledge score. Nevertheless, as stated above, Norway was the only Nordic country that did not have 
between-school differences regarding open classroom climates in 2016. In Norway, perhaps, inequalities reside in access to learning within schools.

\subsubsection{What Should Schools Do to Reduce Inequalities in Civic Competence?}

The chapter's results identified that civic learning (open classroom climates and inschool civic participation) in each country in both studies is likely to be enhancing each of the three forms of civic competence (civic knowledge, citizenship selfefficacy, and intended future electoral participation). Equally, the results indicated that when students accessed these forms of learning, disadvantaged students appeared to benefit either the same or more than their advantaged peers. Perhaps the most important finding of this chapter is that when less advantaged students get access to civic learning, they can experience mitigating/compensatory effects on their civic development. This was found most frequently when less advantaged students were able to access in-school civic participation, which appeared to develop their intended future electoral participation-although it should be noted that in keeping with the results found in this field these effects were not large. In Finland, in-school civic participation also compensated for inequalities in civic knowledge in 2009 by quite a considerable size. These results of the benefits of in-school civic participation is new to the field of citizenship education, as previous research has only found mitigating effects for citizenship education (Deimel et al. 2020; Gainous and Martens 2012; Hoskins et al. 2017; Hoskins and Janmaat 2019) or open classroom climates (Campbell 2008). Thus, we can conclude that the targeted provision of access to civic learning-in particular in-school civic participation-for less advantaged students can provide an important tool that schools can use to combat inequalities in civic competence and has the potential to reduce future inequalities in political engagement.

Acknowledgement We would like to thank the IEA research team led by Dr. Rolf Stretholt for their support in conducting the multilevel analysis.

\section{References}

Achen, C. H., \& Blais, A. (2010). Intention to vote, reported vote and validated vote. Paper presentation. APSA 2010 Annual Meeting, Orlando, FL.

Aaberge, R., André, C., Boschini, A., Calmfors, L., Gunnarsson, K., Hermansen, M., Langørgen, A., et al. (2018). Increasing income inequality in the Nordics: Nordic economics policy review 2018. Copenhagen, Denmark: Nordic Council of Ministers. 
Almgren, E. (2006). Att fostra demokrater: Om skolan i demokratin och demokratin i skolan [Educating Democrats: About school in democracy and democracy in school] (PhD dissertation). Acta Universitatis Upsaliensis, Uppsala. http://urn.kb.se/resolve?urn=urn:nbn:se:uu:diva6890.

Barrett, M. (2020). The Council of Europe's reference framework of competences for democratic culture: Policy context, content and impact. London Review of Education, 18(1), 1-17.

Bauer, P., \& Riphahn, R. T. (2006). Timing of school tracking as a determinant of intergenerational transmission of education. Economic Letters, 91(1), 90-97. https://doi.org/10.1016/j.eco nlet.2005.11.003.

Beck, P. A., \& Jennings, M. K. (1982). Pathways to participation. American Political Science Review, 76(1), 94-108.

Ben-Porath, S. (2013). Deferring virtue: The new management of students and the civic role of schools. Theory and Research in Education, 11(2), 111-128. https://doi.org/10.1177/147787851 3485172 .

Bischoff, K. (2016). The civic effects of schools: Theory and empirics. Theory and Research in Education, 14(1), 91-106. https://doi.org/10.1177/1477878515619794.

Blais, A. (2000). To vote or not to vote? The merits and limits of rational choice theory. Pittsburgh, PA: University of Pittsburgh Press.

Campbell, D. E. (2008). Voice in the classroom: How an open classroom climate fosters political engagement among adolescents. Political Behavior, 30(4), 437-454.

Castillo, J. C., Miranda, D., Bonhomme, M., Cox, C., \& Bascopé, M. (2015). Mitigating the political participation gap from the school: The roles of civic knowledge and classroom climate. Journal of Youth Studies, 18(1), 16-35.

Deimel, D., Hoskins, B., \& Abs, H. J. (2020). How do schools affect inequalities in political participation: Compensation of social disadvantage or provision of differential access? Educational Psychology, 40(2), 146-166. https://doi.org/10.1080/01443410.2019.1645305.

Finkel, S., \& Ernst, H. (2005). Civic education in post-apartheid South Africa: Alternative paths to the development of political knowledge and democratic values. Political Psychology, 26(3), 333-364. https://doi.org/10.1111/j.1467-9221.2005.00421.x.

Foa, R. S., Klassen, A., Slade, M., Rand, A., \& Williams, R. (2020). The global satisfaction with democracy report 2020. Cambridge, United Kingdom: Centre for the Future of Democracy.

Gainous, J., \& Martens, A. M. (2012). The effectiveness of civic education: Are good teachers actually good for students? American Politics Research, 40(2), 232-266. https://doi.org/10.1177/ $1532673 \times 11419492$.

Geboers, E., Geijsel, F., Admiraal, W., \& ten Dam, G. (2013). Review of the effects of citizenship education. Educational Research Review, 9, 158-173.

Hahn, C. (1998). Becoming political: Comparative perspectives on citizenship education. New York, NY: SUNY Press.

Hooghe, M., \& Dassonneville, R. (2013). Voters and candidates of the future: The intention of electoral participation among adolescents in 22 European countries. Young, 21(1), 1-28. https:// doi.org/10.1177/1103308812467664.

Hoskins, B., Barber, C., Van Nijlen, D., \& Villalba, E. (2011). Comparing civic competence among European youth: Composite and domain-specific indicators using IEA Civic Education Study data. Comparative Education Review, 55(1), 82-110. https://doi.org/10.1086/656620.

Hoskins, B., \& Janmaat, J. G. (2019). Education, democracy and inequality: Political engagement and citizenship education in Europe. London, United Kingdom: Palgrave Macmillan. https:// www.springer.com/gb/book/9781137489753.

Hoskins, B., Janmaat, J. G., \& Melis, G. (2017). Tackling inequalities in political socialisation: A systematic analysis of access to and mitigation effects of learning citizenship at school. Social Science Research, 68, 88-101. https://doi.org/10.1016/j.ssresearch.2017.09.001.

Hoskins, B., Janmaat, J. G., \& Villalba, E. (2012). Learning citizenship through social participation outside and inside school: An international, multilevel study of young people's learning of 
citizenship. British Educational Research Journal, 38(3), 419-446. https://doi.org/10.1080/014 11926.2010.550271.

Hoskins, B., \& Mascherini, M. (2009). Measuring active citizenship through the development of a composite indicator. Social Indicator Research, 90(3), 459-488. https://doi.org/10.1007/s11205008-9271-2.

Hoskins, B., Saisana, M., \& Villalba, C. M. H. (2014). Civic competence of youth in Europe: Measuring cross-national variation through the creation of a composite indicator. Social Indicator Research, 123(2), 431-457. https://doi.org/10.1007/s11205-014-0746-z.

Huber, R. A., \& Ruth, S. P. (2017). Mind the gap! Populism, participation and representation in Europe. Swiss Political Science Review, 23(4), 462-484. https://doi.org/10.1111/spsr.12280.

Keating, A., \& Janmaat, J. G. (2016). Education through citizenship at school: Do school activities have a lasting impact on youth political engagement? Parliamentary Affairs, 69(2), 409-429. https://doi.org/10.1093/pa/gsv017.

Köhler, H., Weber, S., Brese, F., Schulz, W., \& Carstens, R. (2018). ICCS 2016 user guide for the international database. Amsterdam, the Netherlands: International Association for the Evaluation of Educational Achievement (IEA). https://www.iea.nl/publications/user-guides/iccs-2016-userguide-international-database.

Knowles, R. T., Torney-Purta, J., \& Barber, C. (2018). Enhancing citizenship learning with international comparative research: Analyses of IEA civic education datasets. Citizenship Teaching \& Learning, 13(1), 7-30. https://doi.org/10.1386/ctl.13.1.7_1.

Kriesi, H. (2014). The populist challenge. West European Politics, 37(2), 361-378.

Lundahl, L. (2016). Equality, inclusion and marketization of Nordic education: Introductory notes. Research in Comparative and International Education, 11(1), 3-12. https://doi.org/10.1177/174 5499916631059.

McDevitt, M., \& Kiousis, S. (2006). Experiments in political socialization: Kids voting USA as a model for civic education reform (Working Paper No. 49). CIRCLE, University of Maryland. http://www.civicyouth.org.

McFarland, D. A., \& Thomas, R. J. (2006). Bowling young: How youth voluntary associations influence adult political participation. American Sociological Review, 71(3), 401-425.

Moeller, J., De Vreese, C., Esser, F., \& Kunz, R. (2014). Pathway to political participation: The influence of online and offline news media on internal efficacy and turnout of first-time voters. American Behavioral Scientist, 58(5), 689-700.

Muthén, L. K., \& Muthén, B. O. (2012). Mplus: Statistical analysis with latent variables. User's guide (Version 7). Los Angeles, CA: Muthén \& Muthén.

Nolan, K. (2018). I'm a kid from the Bronx': A reflection on the enduring contributions of Willis's cultural production perspective in 'Learning to Labour'. Ethnography, 19(4), 464-478. https:// doi.org/10.1177/1466138118780869.

OECD. (2019). PISA 2018 results (Volume II): Where all students can succeed. Paris, France: OECD Publishing. https://doi.org/10.1787/b5fd1b8f-en.

Parker, P. D., Marsh, H.W., Jerrim, J.P., Guo, J., \& Dicke, T. (2018). Inequity and excellence in academic performance: Evidence from 27 countries. American Educational Research Journal, 55(4), 836-858. https://doi.org/10.3102/0002831218760213.

Persson, M. (2015). Classroom climate and political learning: Findings from a Swedish panel study and comparative data. Political Psychology, 36(5), 587-601. https://doi.org/10.1111/pops.12179.

Piketty, T. (2013). Le Capital au XXIe siècle [Capital in the twenty-first century]. Paris, France/New York, NY: Édotopms de Seuil/Harvard University Press.

Quintelier, E. (2008). Who is politically active: The athlete, the scout member or the environmental activist? Young people, voluntary engagement and political participation. Acta Sociologica, 51(4), 355-370. https://doi.org/10.1177/0001699308097378.

Quintelier, E., \& Hooghe, M. (2012, May 11). Discussing politics at school. Does an open classroom climate contribute to the willingness to participate in political life? Conference Paper: Transformations of the State, Oxford, United Kingdom. 
Schulz, W., Ainley, J., Fraillon, J., Losito, B., Agrusti, G., \& Friedman, T. (2017). Becoming citizens in a changing world: IEA International Civic and Citizenship Education Study 2016 international report. Cham, Switzerland: Springer. https://link.springer.com/book/10.1007\%2F978-3-319-739 63-2.

Schulz, W., Carstens, R., Losito, B., \& Fraillon, J. (2018). ICCS 2016 technical report. Amsterdam, the Netherlands: International Association for the Evaluation of Educational Achievement (IEA). https://www.iea.nl/sites/default/files/2019-07/ICCS\%202016_Technical\% 20Report_FINAL.pdf.

Skolverket. (2019). PISA 2018: 15-åringars kunskaper i läsförståelse, matematik och naturvetenskap [PISA 2018: 15-year-olds' knowledge in reading, mathematics and science]. Stockholm, Sweden: Skolverket (Swedish National Agency for Education).

Telhaug, A. O., Mediås, O. A., \& Aasen, P. (2006). The Nordic model in education: Education as part of the political system in the last 50 years. Scandinavian Journal of Educational Research, 50(3), 245-283. https://doi.org/10.1080/00313830600743274.

ten Dam, G., \& Volman, M. (2004). Critical thinking as a citizenship competence: Teaching strategies. Learning and Instruction, 14(4), 359-379. https://doi.org/10.1016/j.learninstruc.2004. 01.005 .

Torney-Purta, J. (2002). The school's role in developing civic engagement: A study of adolescents in twenty-eight countries. Applied Developmental Science, 6(4), 203-212. https://doi.org/10.1207/ s1532480xads0604_7.

Widtfeldt, A. (2018). The growth of the radical right in Nordic countries: Observations from the past 20 years. Stockholm, Sweden: Transatlantic Council on Migration. Washington, DC: Migration Policy Institute.

Professor Bryony Hoskins has a chair in Comparative Social Science at the University of Roehampton. She is an internationally renowned expert on political socialization specializing in political engagement across Europe and the Middle East. Her current funded research projects are on Post-16 Educational Trajectories and Social Inequalities in Political Engagement (Funded by Nuffield Foundation), Effective education interventions for teaching and learning European Citizenship for disadvantaged young people (funded by Robert Bosch Foundation) and Measuring Life Skills and Citizenship Education in the Middle East and North Africa (funded by UNICEF).

Lihong Huang is a research professor in youth research with extensive research experience in school education and survey studies. She was the national research coordinator of the Norwegian IEA International Civic and Citizenship Education Study (ICCS) (2016) with strong expertise in research methodology and cross-country quantitative comparative analyses. She currently leads a research project on democratic citizenship education in Norwegian school system (DEMOCIT) funded by the Research Council of Norway.

Cecilia Arensmeier, associate professor in political science, works as a teacher and researcher at Örebro University. Her research mainly concerns civic education and education policy. She was a research partner to the Swedish National Agency for Education in IEA's International Civic and Citizenship Education Study (ICCS) 2009 and ICCS 2016, and has a similar assignment for ICCS 2022. 
Open Access This chapter is licensed under the terms of the Creative Commons Attribution 4.0 International License (http://creativecommons.org/licenses/by/4.0/), which permits use, sharing, adaptation, distribution and reproduction in any medium or format, as long as you give appropriate credit to the original author(s) and the source, provide a link to the Creative Commons license and indicate if changes were made.

The images or other third party material in this chapter are included in the chapter's Creative Commons license, unless indicated otherwise in a credit line to the material. If material is not included in the chapter's Creative Commons license and your intended use is not permitted by statutory regulation or exceeds the permitted use, you will need to obtain permission directly from the copyright holder.

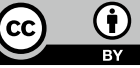

